\title{
New Klebsiella Capsular Antigen, K82, and the Deletion of Five of Those Previously Assigned
}

\author{
IDA $\emptyset R S K O V^{1}$ AND MARY A. FIFE-ASBURY \\ Collaborative Centre for Reference and Research on Escherichia (WHO), Statens Seruminstitut, DK-2300 \\ Copenhagen S, Denmark, ${ }^{1}$ and Enteric Section, Center for Disease Control, Atlanta, Georgia $30333^{2}$
}

A new Klebsiella capsular antigen, K82, is established. K73, K75, K76, K77, and $\mathrm{K} 78$ are deleted from the scheme. K73 is a strain of Enterobacter aerogenes, and the others are identical to or in practice serologically indistinguishable from previously established $\mathrm{K}$ antigens. The deleted numbers will not be assigned by our laboratories to any new $\mathrm{K}$ antigen.

Seventy-two Klebsiella $\mathrm{K}$ antigens had been established by $1955(1,3,5-7,11)$. Antigens K73 through K80 were reported in 1962 (8) and 1963 (2), and K81 was reported in 1975 (10). This paper contains a description of a new capsular antigen, K82, Klebsiella strain CDC 3454-70.

This strain was isolated from a carpet during an epidemiological survey in the U.S. in 1970 and was classified as Klebsiella penumoniae (4). Table 1 shows the biochemical pattern of K82. K82 does not react with any antiserum against previously established $\mathrm{K}$ antigens. K82 antiserum gives capsular quellung with $\mathrm{K} 8$ and $\mathrm{K} 20$, but at such low titer levels that absorptions have not been carried out.

Because of some confusion concerning the characteristics of capsular antigens K73 through $\mathrm{K} 80$, K82 was for some years mistakenly identified as K76 in the U.S. When these K antigens were reexamined in our laboratories, we found that only K74, K79, and K80 were actually new. $\mathrm{K} 75, \mathrm{~K} 76, \mathrm{~K} 77$, and $\mathrm{K} 78$ were identical to or so closely related to already established $\mathrm{K}$ antigens that it would be incorrect to call them new. K73 was a barely encapsulated strain of Enterobacter aerogenes. The cross-reactions of the abovementioned types were as follows: K75 was identical to or very closely related to $\mathrm{K} 68$, as was $\mathrm{K} 76$ to K46, K77 to K39, and K78 to K15. The correction of these erroneous identifications left numerical gaps in the Klebsiella $\mathrm{K}$ antigen system. Since such gaps could be misleading, the Center for Disease Control laboratory used the numbers to document new types (previously designated as K74, K79, and $\mathrm{K} 80$ and strain CDC 3454-70) and assigned them $K$ antigen listings of $\mathrm{K} 73, \mathrm{~K} 74, \mathrm{~K} 75$, and $\mathrm{K} 76$, respectively.

However, at present we agree that (i) any attempt to fill the gaps in the Klebsiella $\mathrm{K}$ antigen system created as described above is confusing since the numbers have all been widely used in the literature $(2,8,9)$, and (ii)
TABLE 1. Biochemical reactions of Klebsiella pneumoniae K82

\begin{tabular}{|c|c|}
\hline Test or substrate & Reaction $^{\prime 2}$ \\
\hline Dulcitol $\ldots \ldots \ldots \ldots \ldots \ldots \ldots$ & - \\
\hline Adonitol, sorbitol, arabinose, maltose, $x y-$ & \\
\hline $\begin{array}{l}\text { lose, rhamnose, salicin, inositol, lactose, } \\
\text { sucrose, raffinose, sorbose }\end{array}$ & + \\
\hline Mannitol $\ldots \ldots \ldots \ldots$ & ++ \\
\hline$\ldots \ldots \ldots \ldots \ldots \ldots \ldots$ & ++ \\
\hline$\ldots \ldots \ldots \ldots \ldots \ldots$ & - \\
\hline $\mathrm{H}_{2} \mathrm{~S} \ldots$ & - \\
\hline Gelatin $\ldots \ldots \ldots \ldots \ldots \ldots \ldots \ldots \ldots \ldots \ldots \ldots \ldots$ & - \\
\hline Ammonium glucose $\ldots \ldots \ldots \ldots \ldots \ldots$ & + \\
\hline Ammonium citrate $\ldots \ldots \ldots \ldots \ldots \ldots$ & + \\
\hline $\mathrm{KNO}_{3}$ & + \\
\hline Voges-Proskauer & + \\
\hline Methyl red $\ldots \ldots \ldots \ldots \ldots \ldots$ & - \\
\hline 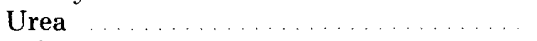 & + \\
\hline $\mathrm{D}$-Tartrate $\ldots \ldots \ldots \ldots \ldots \ldots \ldots \ldots \ldots \ldots \ldots \ldots$ & - \\
\hline Sodium citrate $\ldots \ldots \ldots \ldots \ldots \ldots$ & - \\
\hline Mucate & + \\
\hline Malonate. & + \\
\hline $\mathrm{KCN} \ldots \ldots \ldots \ldots$ & + \\
\hline Lysine decarboxylase & + \\
\hline Arginine dihydrolase $\ldots$ & - \\
\hline Ornithine decarboxylase $\ldots \ldots \ldots \ldots \ldots$ & - \\
\hline Motility & - \\
\hline
\end{tabular}

${ }^{a}$ Symbols: + , positive for sugars after 1 day; ++ , acid and gas after 1 day; - , negative after 14 days.

our laboratories will designate the capsule antigens and strain numbers following K72 as follows: K73, deleted; K74, 371; K75, deleted; K76, deleted; K77, deleted; K78, deleted; K79, 325; K80, 708; K81, 370; K82, 3454-70.

\section{REPRINT REQUESTS}

Address reprint requests to: Dr. Mary Alyce Fife-Asbury, Enteric Section, Center for Disease Control, Atlanta, GA 30333.

\section{LITERATURE CITED}

1. Brooke, M. S. 1951. Further capsular antigens of Klebsiella thin strains. Acta Pathol. Microbiol. Scand. 28:313-327.

2. Durlakowa, I., J. Maresz-Babczyszyn, A. Przando- 
Hesssek, and Z. Lusar. 1963. New K antigenic types of bacilli of the genus Klebsiella. Arch. Immunol. Ther. Exp. 11:549-562.

3. Edmunds, P. N. 1954. Further Klebsiella capsule types. J. Infect. Dis. 94:65-71.

4. Edwards, P. R., and W. H. Ewing. 1972. Identification of Enterobacteriaceae, 3rd ed. Burgess Publishing Co., Minneapolis.

5. Edwards, P. R., and M. A. Fife. 1952. Capsule types of Klebsiella. J. Infect. Dis. 91:92-104.

6. Edwards, P. R., and M. A. Fife. 1955. Studies on the Klebsiella-Aerobacter group of bacteria. J. Bacteriol. 70:382-390.
7. Kauffmann, F. 1949. On the serology of the Klebsiella group. Acta Pathol. Microbiol. Scand. 26:381-406.

8. Maresz-Babczyszyn, J. 1962. New antigenic types of Klebsiella bacilli. Arch. Immunol. Ther. Exp. 10:589-617.

9. Nimmich, W. 1971. Uber die spezifischen Polysaccharide (K-antigene) der Klebsiella Typen K73-K80. Acta Biol. Med. Ger. 26:397-403.

10. Nimmich, W., and W. Munter. 1975. Ein neuer Klebsiella serotype K81. Z. Allg. Mikrobiol. 15:127-129.

11. Orskov, I. 1955. Serological investigations in the Klebsi ella group. 1. New capsule types. Acta Pathol. Microbiol. Scand. 36:449-453. 